\title{
Effect of Social Skills Training Program on Self- Esteem and Aggression among Children in Residential Institutions in Port Said City
}

\author{
Soma Ibrahim Ali ${ }^{1}$; Dr. Sorayia Ramadan Abdel-Fatah ${ }^{2}$; Dr. Amal Sobhy \\ Mahmoud $^{3}$; \& Dr. Sonia Mohamed El-Sayad ${ }^{4}$ \\ ${ }^{1}$ M.Sc. ${ }^{2}$ Professor, ${ }^{3}$ Assistant Professor ${ }^{4}$ Lecturer \\ Psychiatric Nursing and Mental Health Department, Faculty of Nursing, \\ ${ }^{\mathbf{2}}$ Ain-Shams University, ${ }^{\mathbf{1 , 3 , 4}}$ Port Said University.
}

\begin{abstract}
Background: There is now an abundance of global evidence demonstrating serious developmental and psychological problems associated with placement in residential care which reflected in the form of poor self-esteem, aggressive behavior, academic failure and later on, personality disorder. Aim: The study aimed to evaluate the effect of social skill training program on self-esteem and aggression among children in residential institutions in Port-Said City. Subjects and Methods: A quasi-experimental research design was used. The present study was carried out at all governmental residential institutions in Port Said city namely, Al-Nessaieya le Tahseen Al- Seha, Dar Alkaserat, Kafalit Al-Yateem, and Apnaa Ramses. The subject of the study compromised 57 children, $\mathbf{3 6}$ were males and $\mathbf{2 1}$ were females. Three tools were utilized to collect data in this study which are Socio-demographic data questionnaire, Self-esteem inventory scale, and Aggressive behavior scale for children. Results: The study revealed that almost half of the studied children had low self-esteem and the mean scores of verbal aggression among the studied children were slightly higher than mean scores of physical aggression Also, there was a positive effect of the social skills training program in enhancing selfesteem levels and slightly decreasing physical aggression but there was no effect found regarding verbal aggression. Conclusion: The study concluded that there was a significant effect of social skill training program on enhancing self-esteem and slightly decreasing physical aggression, while it had no effect on verbal aggression. Recommendations: broad-based psychosocial intervention programs for resident children and rehabilitation programs are mainly recommended to enhance self-esteem and minimize aggressive behavior among children.
\end{abstract}

Keywords: Residential institutions- Social skills - Self-esteem- Aggression. 


\section{INTRODUCTION}

In the human life cycle, the childhood phase is considered the most important phase for every human being. Giving children the best start in life means ensuring them good health, proper nutrition, and early learning. The well-being of children depends on the ability of families to function effectively. From an environmental perspective, it means safe water, basic sanitation, and protection from violence, abuse, exploitation and discrimination (UNICEF, 2012).

Residential institutions are a kind of homes or shelters where many children are placed together permanently in order to rear children who lived in difficult circumstances and provide them with substitute living arrangements. It may have a governmental or nongovernmental budget affiliated with the Ministry of Social Affairs or from other voluntary agencies under the supervision of the Ministry of Social Affairs (Maher, 2016).

The exact number of children in institutional care is difficult to calculate. Depending on the source, definition and calculation methods, the estimated number of children in institutional care worldwide ranges from 2 to 8 million (Dozier et al, 2012). It is estimated also that 140 million children worldwide are orphans. In Egypt, the Ministry of Social Affairs data indicates that 8,506 children aged 6-18 were living in residential care institutions and there were 16, 019 street children (Unicef Egypt, 2014).

Numerous reviews have reported that residential care continues to be viewed as a 'placement of last resort' for difficult to serve children who have experienced multiple foster placement 'failures' and for whom no alternative placement can be found (Baptista et al, 2013). Children in residential care have been described as engaging in anxiety, depression, suicide, loneliness, high levels of violence and aggression, as well as low selfesteem (Ainsworth \&Hansen, 2009).

According to Gitumu, (2010), self-esteem is a psychological construct which refers to how the self (body and mind) is viewed and valued, that is basically how one feels about himself, how he judges himself in terms of skills, talents, abilities and attributes and how much he values and respects himself. Individuals with low self-esteem are prone to depression because they lack sufficient coping resources, whereas those with high self- 
esteem are able to cope effectively and consequently avoid spiraling downward into depression (Orth, Meier \& Robins, 2009).

On the other hand, aggressive acts are intentional behaviors that may cause psychological or physical harm to others. Aggressive behaviors can be physical, verbal, relational, or sexual. Physical aggression is the intentional use of physical force with the potential to cause disability, injury, or harm (Lalia, 2010), While Orpinas \& Home (2006), define verbal aggression as the intentional use of words with the potential to cause psychological or emotional distress. Children, who are irritable and aggressive, evaluate themselves negatively, they communicate rarely, and they often need social skills training. Studies have been done in the field of the training effect of social skills on some personality characteristic and the results of these studies showed that social skills training significantly increase social growth, self-esteem, personal adequacy, adjustment as well as reduced inappropriate behaviors such aggression and violence (Pasha \& Gorjian, 2010).

Chien, (2003) defined social skills training as a set of psychotherapeutic technique based on social learning theory that has been developed to teach social skills to individuals. It teaches people how they can better communicate and express feeling, thoughts and needs to others. Social skills training programs encourages human interaction and is expected to improve the individual's skills of assertiveness and communication skills. It is also allow the individual to achieve three goals: [a] develop positive interpersonal relationships, [b] enhancing ability to cope with expectations of various social situations, and [c] execute effective communication in social situations (Guadalupe, 2016).

The principal of social skills training is the use of conversation and role-playing in different ways. Social skills training techniques may be incorporated into individuals, groups, and family treatment modalities where there may add measurable benefits (Kneisl, 2009). The psychiatric nurses could implement psycho-education programs to increase social skills, create a social support network and sources for children and their families in houses, schools, and the society, as well as participate in studies about this issue (Smith, 2014). The only drawback to this type of group is that it works best when the group is closed-ended; that is, once the group has been formed, no one is allowed to join until the group has reached its pre-established closure. Members are allowed to propose topics for discussion and the leader serves as a teacher much of the time and facilitates discussion of the proposed topic, also members may from time to time be presenters and serve as 
discussion leaders. Sometimes, psycho-education groups evolve into traditional therapy discussion groups (Black \& Andreasen, 2011).

The role of nurses working with institutionalized children and adolescents in meeting health and psychosocial needs of this population is regarded as critical. A multidisciplinary and multi-sectorial approach is required to identify the complexity of problems that these children and adolescents experience and to bring their abilities to the optimal level to care for themselves. It has been stated that the cooperation of the members of the justice system, social services, and education and health services is important. In this context, psychiatry nurse specialists working in institutions such as forensic psychiatry services, prisons, schools, and so forth should be encouraged to use such training programs (International Society of Psychiatric-Mental Health Nurses, 2011).

\section{Working Definition:}

Social skills: the social skills which were included in the current study are self-care, how to communicate (speaking-listening), attitude toward self, control of anger, respecting and advising others.

\section{AIM OF STUDY:}

The study aimed to evaluate the effect of social skill training program on self-esteem and aggression among children in residential institutions in Port-Said City.

\section{Research Question:}

1. Which type of aggression is most prevalent in residential institutions?

2. What is the effect of social skill training program on self-esteem and aggression among children in residential institutions in Port-Said City?

\section{SUBJECTS AND METHODS}

\section{(I) TECHNICAL DESIGN:}

\section{Research design:-}

A quasi-experimental research design was used in the current study.

\section{Setting:}

The study was carried out at all governmental residential institutions in Port Said city namely: Al-Nessaieya le Tahseen Al- Seha which divided into two parts (Ahbab Allah 
for Female \& Al-Mostakbal for Male), Dar Alkaserat, Kafalit Al-Yateem, and Apnaa Ramses.

\section{Subjects}

The study population comprised children at the previously mentioned settings from both sexes and aged between (7-14) years old. The subjects in this study consisted of 57 children, 36 of them boys and 21 girls.

\section{TOOLS FOR DATA COLLECTION:}

TOOL (I) Socio-demographic Questionnaire: It was consisted of two parts:

1. Part (1): was developed to collect data about socio-demographic characteristics of children such as; age, sex, grade, the number of sibling and causes of placement in a residential institution.

2. Part (2): was developed to collect demographic data about children parents; death, job, and level of education

\section{TOOL (II): Self-esteem inventory scale (SEI)}

Self-esteem inventory (SEI) was modified and translated into Arabic language by Abd El-Raheem Bekheet (1985) who was cited this scale from Cooper Smith (1967), the scale consists of "58" statements, used to measure children attitude towards the self in social, academic, family and personal experience (Abd El-Reheem, 1985 and Draz, 1996). Each statement has words: "like me" or " unlike me".

\section{Scoring system of tool II (SEI):}

One point is given for each positive item answered "like me" and each negative item answered "unlike me". The total raw score was multiplied by two to arrive at a total selfscore which was ranged from $(0: 116)$. The scores of each group of the study were arranged in ascending order and divided into four quartiles, the first one was low selfesteem, the second and the third were moderate self-esteem and high self-esteem was the fourth quartile (Booth, 1992).

a) Low self-esteem is equal to or less than 62 .

b) Moderate self-esteem is equal to or greater than 64 .

c) High self-esteem is equal to or greater than 80 . 


\section{TOOL (III): Aggressive behavior scale for children (Appendix III):}

This scale was developed by Mansy and Hassan (1998) and adapted by Abd ElGhany (2008). It is an Egyptian Arabic Inventory. It consists of 73 items. It assesses two types of aggression; verbal aggression and physical aggression. The items are either positive or negative statement. Each item should be answered by selecting one of the three alternatives, "Yes"=2, "No= 1, "don't know"=0.

The score is reversed in the negative statement "Yes"=1, " No"=2, "don't know"=0. The statement measured verbal aggression includes 2,3,5-9,13,16$19,22,23,25,27,29,32,33,41,49,50,52-59,60,62-65,68-71$. The statement measured physical aggression includes, 1,4,10,11,12,14,15,21,24,26,30,31,34-40,42-48,51$61,66,67,72,73$.

\section{(II) OPERATIONAL DESIGN:}

\section{Preparatory phase}

A review of the past, current related literature using the available local and international books, magazines, and periodical to get acquainted with the research problem, to develop the study tools.

\section{Pilot Study:}

A pilot study was carried out on $10 \%$ of the study subjects to test the tools before starting the data collection. It was conducted at the time from the beginning of September (2015). The purposes of the pilot study were to test the clarity, applicability and the feasibility of the study tools and to estimate the time needed to fill in the tools. It also helped to find out any obstacles and problems that might interfere with data collection.

Field of work: The study was carried out through the following phases:

(1) Assessment:

A comfortable and private place was chosen for sitting with the studied children. Orientation was done about researcher name, purpose, and content of the study tools. The researcher set with every child alone for 45-60 minutes to fill the study tools. It took about one month, from the first of October to the end of October 2015 nearly 4 hours daily for 3 days a week at 3 to 7 p.m.; then the program starts at the beginning of November 2015 . 


\section{(2) Program implementation phase:}

The social skills training program was conducted for 3 months (from 1 November 2015 to the end of January 2016); nearly 3 hours daily for 3 days a week at 3 to 6 p.m. In addition, the program was implemented through 12 sessions; each session takes 45-60 minutes. This was achieved through using of several teaching methods such as lecture, discussion, storytelling, and brainstorming. Videos, pictures, and role-play were used as media.

\section{Program Evaluation Phase:}

Reassessment of the children was done two times after application of the program using the same study tools to investigate whether the change persisted or not, except sociodemographic tool used only once at the preprogram period. The first assessment was carried out immediately post program to reassess the children after the application of the program, which begins at the beginning of February to the end of February 2016; nearly 3 hours daily for 3 days a week at 3 to 6 p.m. Finally, the second assessment was carried out 3 months later using the same previous tools and begin from first of May to the end of May 2016.

\section{(III) ADMINISTRATIVE DESIGN}

Before starting any step in the study, an official letter was issued from the dean of the Faculty of Nursing to the director of Social Affairs in Port-Said city requesting their cooperation and permission to conduct the study in the institutions, after explaining the aim of the study.

\section{Ethical Considerations:}

The researcher explained the aim of the study to the director of each institution to take their permission to carry out the study. Before starting the interview, a verbal consent was taken from the children and after a short introduction about the aim of the study in order to gain children's cooperation. The researcher also informed them about their rights to refuse.They were ensured that any information obtained will be confidential and used only for the purpose of the study. In addition, they were told that there was no right or wrong answers; it is a just honest expression of their feelings and behaviors. 


\section{(IV) STATISTICAL DESIGN:}

Data entry and statistical analysis were done using SPSS 16.0 statistical software package. Data were presented using descriptive statistics in the form of frequencies and percentages for qualitative variables, and means and standard deviations for quantitative variables. Qualitative categorical variables were compared using chi-square test. Whenever the expected values in one or more of the cells in a $2 \times 2$ tables were less than 5 , Fisher exact test was used instead. In larger than $2 \times 2$ cross-tables, no test could be applied whenever the expected value in $10 \%$ or more of the cells was less than 5 . Statistical significance was considered at $\mathrm{p}$-value $<0.05$.

\section{RESULTS:-}

Table (1) reveals socio-demographic characteristics of the studied children, it is clear that the highest percentage of the studied children (38.6\%) were lived in Kafalit AlYateem while the lowest percentage $(10.5 \%)$ was in Apnaa Ramses. Regarding sex, it was noticed that approximately two third $(63.1 \%)$ of the studied children were male. Also, it was found that more than half of the studied children $(52.6 \%)$ were in the age group of 12 to14 years.

Related to a number of siblings, about half of the studied children $(50.8 \%)$ had no siblings while only $10.5 \%$ of them were had more than six siblings. Concerning causes of presence in an institution, it was noticed that the main cause was the parents' divorce $45.6 \%$ followed by $42.1 \%$ were a foundling. In relation to the frequency of inside and outside visits, the table revealed that most of the studied children $(66.6 \%)$ never had inside visits as well as $87.7 \%$ outside visits.

Table (2): Showed that almost half of the studied children (45.6\%) had low selfesteem levels, while the lowest percentage of them (19.3\%) had high self-esteem.

Table (3): showed that mean scores of verbal aggression among the studied children $57.70+9.19$ were slightly higher than mean scores of physical aggression $(57.70+9.19,56.46+8.83)$ respectively.

Table (4) compared self-esteem levels among the studied children throughout pre, post and follow up of implementation of social skill training program. As shown in the table, there is decrease in the percentage of children who had low self-esteem during 
post implementation of the program $(24.56 \%)$, and the percentage seemed to be increased during follow-up (28.7\%).

Additionally, there was an increase in the percentage of children who had moderate level of self-esteem during post implementation of the program (45.61\%), while the percentage decreased during the follow-up and reached $43.86 \%$. Less than one quarter of the studied children (19.3\%) had high self-esteem before the program implementation and the percentage increased to be $29.8 \%$ immediately after implementation of the program b slightly decreased during follow up period (28.7\%). Finally, there was a highly statistical significant difference found among the three phases of program (throughout pre, post and follow up) in relation to self-esteem levels $(\mathrm{P}<0.01)$.

Table (5) illustrates that there were statistically significant differences noticed between pre and immediate post implementation social skills training program $(\mathrm{P} 1=$ 0.08) regarding children physical aggression. The mean score and SD of physical aggression were $56.46 \pm 8.83,55.88 \pm 10.78$ and $55.13 \pm 9.28$ respectively at the preprogram, immediate post program and Follow-up. Regarding verbal aggression, there were no statistically significant differences found in relation to the three phases of the program. 
Table (1): Socio-demographic characteristics of the studied children $(\mathrm{N}=57)$ :

\begin{tabular}{|c|c|c|}
\hline Item & $\begin{array}{l}\text { Frequency } \\
\mathrm{N}=\mathbf{5 7}\end{array}$ & $\begin{array}{l}\text { Percent } \\
\%\end{array}$ \\
\hline $\begin{array}{l}\text { Institution name } \\
\text { 1. Al-Nessaieya le Tahseen al Seha } \\
\text { 2. Dar-Alkaserat } \\
\text { 3. Kafalit Al-Yateem } \\
\text { 4. Apnaa Ramses }\end{array}$ & $\begin{array}{c}19 \\
10 \\
22 \\
6\end{array}$ & $\begin{array}{l}33.3 \\
17.5 \\
38.6 \\
10.5\end{array}$ \\
\hline $\begin{array}{l}\text { Sex } \\
\text { Boys } \\
\text { Girls } \\
\end{array}$ & $\begin{array}{l}36 \\
21\end{array}$ & $\begin{array}{l}63.1 \\
36.8\end{array}$ \\
\hline $\begin{array}{l}\text { Age ( years ) } \\
6- \\
9- \\
12-14\end{array}$ & $\begin{array}{c}4 \\
23 \\
30 \\
\end{array}$ & $\begin{array}{l}7.02 \\
40.3 \\
52.6\end{array}$ \\
\hline $\begin{array}{l}\text { Causes of presence in institution } \\
\text { Mother death } \\
\text { Father death } \\
\text { Low socio-economic status } \\
\text { Divorce } \\
\text { Foundling }\end{array}$ & $\begin{array}{c}1 \\
2 \\
4 \\
26 \\
24\end{array}$ & $\begin{array}{r}1.8 \\
3.5 \\
7.02 \\
45.6 \\
42.1 \\
\end{array}$ \\
\hline $\begin{array}{l}\text { Children status } \\
\text { Have parents } \\
\text { - Having fathers and mothers } \\
\text { - Father death } \\
\text { - Mother death } \\
\text { Not have parents } \\
\end{array}$ & $\begin{array}{c}33 \\
30 \\
2 \\
1 \\
24\end{array}$ & $\begin{array}{c}57.9 \\
90.9 \\
6.1 \\
3.0 \\
42.1\end{array}$ \\
\hline $\begin{array}{l}\text { Number of sibling } \\
1-3 \\
4-6 \\
\text { More than } 6 \\
\text { No sibling }\end{array}$ & $\begin{array}{c}9 \\
13 \\
6 \\
29\end{array}$ & $\begin{array}{l}15.7 \\
22.8 \\
10.5 \\
50.8\end{array}$ \\
\hline $\begin{array}{l}\text { Presence of institutionalized sibling } \\
\text { Yes } \\
\text { No }\end{array}$ & $\begin{array}{c}6 \\
51\end{array}$ & $\begin{array}{l}10.5 \\
89.4\end{array}$ \\
\hline $\begin{array}{l}\text { Frequency of receiving inside visits/month } \\
\text { Never } \\
\text { Once or twice }\end{array}$ & $\begin{array}{l}38 \\
19\end{array}$ & $\begin{array}{l}66.6 \\
33.4\end{array}$ \\
\hline $\begin{array}{l}\text { Frequency of going outside visits/month } \\
\text { Never } \\
\text { Once or twice }\end{array}$ & $\begin{array}{c}50 \\
7\end{array}$ & $\begin{array}{l}87.7 \\
12.3\end{array}$ \\
\hline
\end{tabular}


Table (2): Distributions of self-esteem levels among the studied children(N=57):

\begin{tabular}{|c|c|c|}
\hline \multirow{2}{*}{ Items } & \multicolumn{2}{|c|}{$\begin{array}{c}\text { Institutionalized children } \\
\mathbf{N = 5 7}\end{array}$} \\
\cline { 2 - 3 } & $\mathbf{N o}$ & \% \\
\hline Low (14-62) & 26 & 45.6 \\
\hline Moderate (64-78) & 20 & 35.1 \\
\hline High (80-100) & 11 & 19.3 \\
\hline
\end{tabular}

Table (3): Distribution of types of aggression among the studied children( $N=57)$ :

\begin{tabular}{|c|c|}
\hline \hline \multirow{2}{*}{ Types of Aggressive behavior } & $\begin{array}{c}\text { Institutionalized children } \\
\mathbf{N}=\mathbf{5 7}\end{array}$ \\
\cline { 2 - 2 } & $\mathbf{M e a n} \pm \mathbf{S d}$ \\
\hline \hline Verbal aggression & $57.70+9.19$ \\
\hline \hline Physical aggression & $56.46+8.83$ \\
\hline
\end{tabular}

Table (4): The effect of social skills training program on self-esteem levels among the studied children $(\mathrm{N}=57)$ :

\begin{tabular}{|c|c|c|c|c|c|c|c|c||}
\hline \multirow{2}{*}{ Self-esteem levels } & \multicolumn{2}{|c|}{$\begin{array}{c}\text { Pre-program } \\
\text { N=57 }\end{array}$} & \multicolumn{2}{c|}{$\begin{array}{c}\text { Immediate } \\
\text { Post program } \\
\text { N=57 }\end{array}$} & \multicolumn{2}{c|}{$\begin{array}{c}\text { Follow-up } \\
\text { N=57 }\end{array}$} & \multirow{2}{*}{$\chi^{2}$} & \multirow{2}{*}{ p } \\
\cline { 2 - 9 } & No & $\%$ & No & \% & No & \% & & \\
\hline Low (14-62) & 26 & 45.6 & 14 & 24.56 & 16 & 28.07 & 1.24 & \multirow{2}{*}{$0.001 * *$} \\
\hline Moderate (64-78) & 20 & 35.1 & 26 & 45.61 & 25 & 43.86 & 1.27 & \\
\hline High (80-100) & 11 & 19.3 & 17 & 29.82 & 16 & 28.07 & 1.42 & \\
\hline
\end{tabular}

P-value $<0.01$

Table (5): The Effect of social skills training program on the types of aggressive behavior of the studied children( $\mathrm{N}=57)$.

\begin{tabular}{|c|c|c|c|c|c|c|c||}
\hline $\begin{array}{c}\text { Types of } \\
\text { Aggressive } \\
\text { behavior }\end{array}$ & $\begin{array}{c}\text { Preprogram } \\
\text { No=57 }\end{array}$ & $\begin{array}{c}\text { Immediate post } \\
\text { program } \\
\text { No=57 }\end{array}$ & $\begin{array}{c}\text { Follow up } \\
\text { No=57 }\end{array}$ & t-test & df & P1 & P2 \\
\cline { 2 - 5 } & \multicolumn{3}{|c|}{ Mean \pm Sd } \\
\hline $\begin{array}{c}\text { Verbal } \\
\text { Aggression }\end{array}$ & $57.70 \pm 9.19$ & $56.99 \pm 10.93$ & $56.77 \pm 9.95$ & 1.75 & 112 & 0.36 & 0.20 \\
\hline $\begin{array}{c}\text { Physical } \\
\text { Aggression }\end{array}$ & $56.46 \pm 8.83$ & $55.88 \pm 10.78$ & $55.13 \pm 9.28$ & 0.91 & & $0.08 *$ & 0.14 \\
\hline
\end{tabular}

P1=preprogram + Immediate post program

P2=preprogram+ Follow up 


\section{DISCUSSION:}

People deprived of parental care, while being kept at residential institutions, are the most social group in need of psychological security. In fact, they are victims of forcible conditions out of the absence of their families' care and guidance, thereby facing rough psychological, social and economic challenges. These challenges, in turn, may cause them feel insecure. They are mostly susceptible to character disorder due to the society's negative image; thereby causing them feel degraded, different and more sensitive to be introvert and aggressive (Mohamed, 2013). Thus, enhancing their psychological security is a first step towards enhancing their psychological well-being and adaptation to their social environment at the residential institutions. So, the current study aimed at evaluating the effect of social skills training program on self-esteem and aggression among children in residential institutions.

The present study revealed that the highest percentage of the studied children have low self-esteem scores. This might be due to the stigmatization of being unknown, caregivers' mistrust, and neglecting their psychological needs, all these factors may suppress their self-esteem. While the observed improvement of self-esteem might be due to their desire and motivation to increase their shortage feeling and being inferior to their school mates and be independent ones from their institution make efforts to enhance self-esteem. Also, the studied children expressed their emotions, problems, and desires during the program sessions that permit ventilation and relief of their negative feelings.

These foregoing study findings are in agreement with those of Samuel (2010) who studying the effect of parenting on the self-esteem of adolescents in Ghana and found out that children from non-parent families had lower self-esteem. Moreover, Youssef (2004) found that the majority of the institutionalized children have low self-esteem scores. On the other hand, Thomas et al, (2014) who studied the levels of self-esteem among students of single and dual parent families in Kenya suggest that the level of self-esteem of a student does not depend on the type of parenthood if the students 'school environment and teaching conditions are the same.

Regarding the comparison between self-esteem levels among the studied children throughout pre, post, and follow-up of the implementation of social skill training program. The present study revealed that there were highly statistically significant differences 
found among the phases of the program (throughout pre, post, and follow-up) in relation to self-esteem levels. Levels of self-esteem seemed to be increased after implementation and follow-up of the program

This relation may be due to skilled individuals are presumably effective in social interactions; their mastery of social situations should enhance their 'social self-esteem'the positive self-evaluation derived from feeling good about one's social self. Possession of social skills, specifically skills and abilities in areas such as impression management, playing various social roles, and communicating effectively, should lead to a very positive social self-image. According to (Moe \& Zeiss, 2010), It may be the case that possession of social skills leads to a form of 'social' self-efficacy-a belief in one's ability to master diverse social situations. Thus, it is expected that there should be positive relationships between measures of social skills/competence and measures of self-esteem.

According to Bahador et al (2015), the explanation of the relation of social skills and self- esteem to say teaching social skills to children improves the beliefs, attitudes, and motivations of their, their interests, tasks, and which expression changed. Also, their judgment about feelings, relationships and expectations of the family has changed and the level of their intelligence, to the school, classmates, teachers and school to create positive change. Similar to the foregoing current study results Maher (2016) who studied the effect of social skills training program on self-esteem and social skills among adolescents and found that there was the highly statistically significant difference between pre and post intervention on the self-esteem of adolescents. However, a study carried out by (Babakhani, 2011) contradicted this study, who studied the effects of social skills training on self-esteem and aggression among male adolescents, he found that there were no statistically significant differences between pre and post intervention on the self-esteem of adolescents.

Aggression is a very much part of the lives of the children's institutions, and it seems to be part of a boarder picture of problems associated with risk for and experience of children's institutions as stated by Khamis, (2013). The present study revealed that mean scores of verbal aggression among the studied children were slightly higher than mean scores of physical aggression. This may be due the rules of institutions which refuse physical aggression and punishing these behaviors. In disagreement with this, El-Masry et 
al (2016), who studied physical and verbal aggression among adolescent school students prevalence in Egypt, found that physical aggression was more prevalent than verbal aggression.

According to the results of the current study, the social skills training program has little impact on the total scores of aggressive behaviors. Statistical significant differences were found among pre and immediate post implementation regarding physical aggression, while there was no statistically significant difference was found between the phases of the program and verbal aggression. This may mean that verbal aggression is a very difficult to be changed by social skills training program and aggressive behaviors is a pattern or part of life style of the children in institutions. Also, these results may be due to compaction and short time of education, not strengthen of learned behaviors. Probably effectiveness of social skills training is cognitive as well as behavioral. This means that the subjects changed their attitude about social skill in terms of cognitive skills or the style of educator does not support the art of behaving and acceptable manners.

These forgoing present study findings are in agreement with those of Abd Elghany (2008) who studied the effect of social skills training program on the psychosocial profile of homeless children in Egypt and emphasized that there was no statistically significant relation between all stages of social skill training program and verbal aggression among homeless children. On the other hand, the previous research conducted by Babakhani (2011), contradicted this result as he found that there were a significant differences between the experimental and control groups in verbal aggression after social skills training but there isn't significant differences between the experimental and control groups in physical aggression.

In the light of above discussion, it could be said that social skills training can specifically address the needs of children growing up in environments that lack opportunities to develop these skills. Health promotion and prevention programs focusing only on transferal of information are less effective than programs incorporating skills development. 


\section{CONCLUSION:}

Based on the findings of the current study, it is concluded that, almost half of the studied children had low self-esteem and the mean scores of verbal aggression among the studied children were slightly higher than mean scores of physical aggression Also, there was a significant positive effect of social skill training program on enhancing self-esteem and physical aggression among the studied children, while it had no effect on verbal aggression.

\section{RECOMMENDATIONS:}

1. There is a need for broad-based psychosocial intervention programs in dealing with resident children and adolescents, and active treatment programs along with long-term support and rehabilitation programs.

2. Further work on large scale epidemiological studies concerning the psychological problems among institutionalized children especially depression, aggression, and child abuse.

3. Empowerment programs are necessary to enhance children's social, decision making skills and attachment to their institutions, especially males.

4. Designing guiding program to foster mothers at institutions to ensure that, they have the nurturing practice and knowledge of cognitive, emotional, physical, moral and psychological development of children.

\section{REFERENCES:}

Ainsworth, F. \& Hansen, P. (2015). Therapeutic residential care: Different population, different purpose, different costs. Children Australia, 40(4): 342-7.

Babakhani, N. (2011). The effects of social skills training on self- esteem and aggression male adolescents. Journal of Social and Behavioral Science, 30, 1565-70.

Bahador, G., Abeditorab, R., Mahdi, M., Hosain, M., \&Farjami, A. (2015). The effectiveness of teaching social skills on self-esteem and dimensions (self, family, 
social and academic) in students with learning disabilities. Journal of Applied Environmental and Biological Sciences, 5(11S) 689-94.

Baptista, J., Belsky, J., Martins, C., Silva, J., Marques, S., \& Mesquita, A. (2013). Social withdrawal behavior in institutionalized toddlers: Individual, early family and institutional determinants. Infant Mental Health Journal, 34(6): 562-73.

Black, D. , \& Andreasen, N. (2011). Introductory textbook of psychiatry. $5^{\text {th }}$ ed, American Psychiatric Publishing .Washington, DC. London. England.

Chien, $H ., K u, H ., L u, R ., C h u, H ., \& C h o u, K$. (2003). Effect of social skill training on improving social skills of patients with schizophrenia. Archives of psychiatric nursing, 17(5): 228-64.

Dozier, M., Zeanah, C., Wallin, A., \&Shauffer, C. (2012). Institutional care for youngchildren: Review of literature and policy implications. Social Issues and Policy Review, 6(1): 1-25.

Draz, S. (1996). Effects of parental deprivation on the child from six to twelve years of life, Unpublished Master Thesis, faculty of nursing, Ain-shams University.

El-Masry, N., Fouad, A., Khalil, D. \& Sherra, K. (2016). Physical and verbal aggression among adolescent school students in Sharkia, Egypt: prevalence and risk factors. Egyptian Journal of Psychiatry, 37(3): 166-73.

Gitumu, M. (2010). Relationship between students' self-esteem and Orphan hood in Kirinyaga, Nyeri North and Nyeri South districts of Kenya. Unpublished Doctoral Dissertation.

Guadalupe, F. (2016). Social skills training for autistic children: A comparison study between inclusion and mainstreaming education. California Lutheran University. Research Article, 1 ( 3): 16-8. 
International Society of Psychiatric-Mental Health Nurses (ISPN) (2011). Prevention of youth violence position. Available at: http: www.ispn-psych.org/docs/301-youth-violence.pdf

Knisel, C. (2009). Liberman R, Wallace C, Blackwell G, Kopelowicz A, Vaccaro J (2004): Social skills training versus psychosocial occupational therapy for persons with persistent schizophrenia. American Journal of Psychiatry; 143 (4):523-6.

Lalia, S. (2010). A Case study of bullying and other aggressive interactions among children in a public middle school. Unpublished Doctoral Dissertation.

Maher, R. (2016). The effectiveness of psycho-social training program on self-esteem among adolescents in residential institutions. Unpublished Doctorate Dissertation. Menofyia University. Faculty of Nursing.

Moe, K. \& Zeiss, A. (2010). Measuring self-efficacy expectations for social skills: A methodological inquiry. Cognitive Therapy and Research, 6(8): 191-205.

Mohamed, A. (2013). Study of the health status of homeless institutionalized children in some social care homes in Assuit governate. Unpublished Master Thesis, Faculty of Nursing. Assuit University.

Obsuth, I., Eisner, M., Malti, T. \& Ribeaud, D. (2015). The developmental relation between aggressive behavior and pro-social behavior: A 5-year longitudinal study. BMC Psychology journal, 6(1): 3-16.

Orpinas, P. \& Home, A. (2006). Bullying prevention. Washington, DC: American Psychological Association.

Orth, U., Meier, L. \& Robins R. (2009). The effects of low self-esteem and stressful events on depression: findings from three longitudinal studies. Journal of Personality and Social Psychology, 97(2 ), 307-21.

Samuel, E. (2010). The effect of parenting on the self-esteem of adolescents in Ghana. Social Work and Social Sciences Review, 12(3): 57-78. 
Smith, F. (2014). The impact of school-based Aggression Replacement Training onemotion regulation and aggressive behavior. Unpublished Doctoral Dissertation. Clinical Psychology, Massey University, Wellington, New Zealand.

Thomas, D. Orlich, F., \&Varley, C. (2014). The levels of self-esteem among students of single and dual parent families in Kenya

Unicef (2012). Children in Residential Institution, April: p. 4.

UNICEF Regional Office for CEE/CIS (2014). Database. Retrieved from http://www.transmonee.org.

Youssef, E. (2004). Assessment of the effect of parental deprivation on self-esteem of children during school age period in Port-Said. Unpublished Master Thesis. Faculty of Nursing. Suez-Canal University.

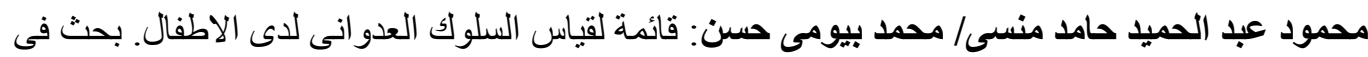

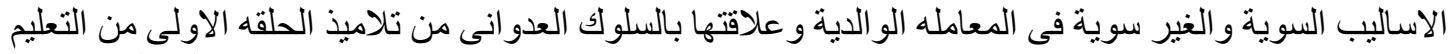
الاساسى بالاسكندرية، كلية التربية-جام 
